Originalveröffentlichung in: Liptay, Fabienne ; Dogramaci, Burcu (Hrsgg.): Immersion in the visual arts and media, Leiden 2016, S. 280-298 (Studies in intermediality ; 9)

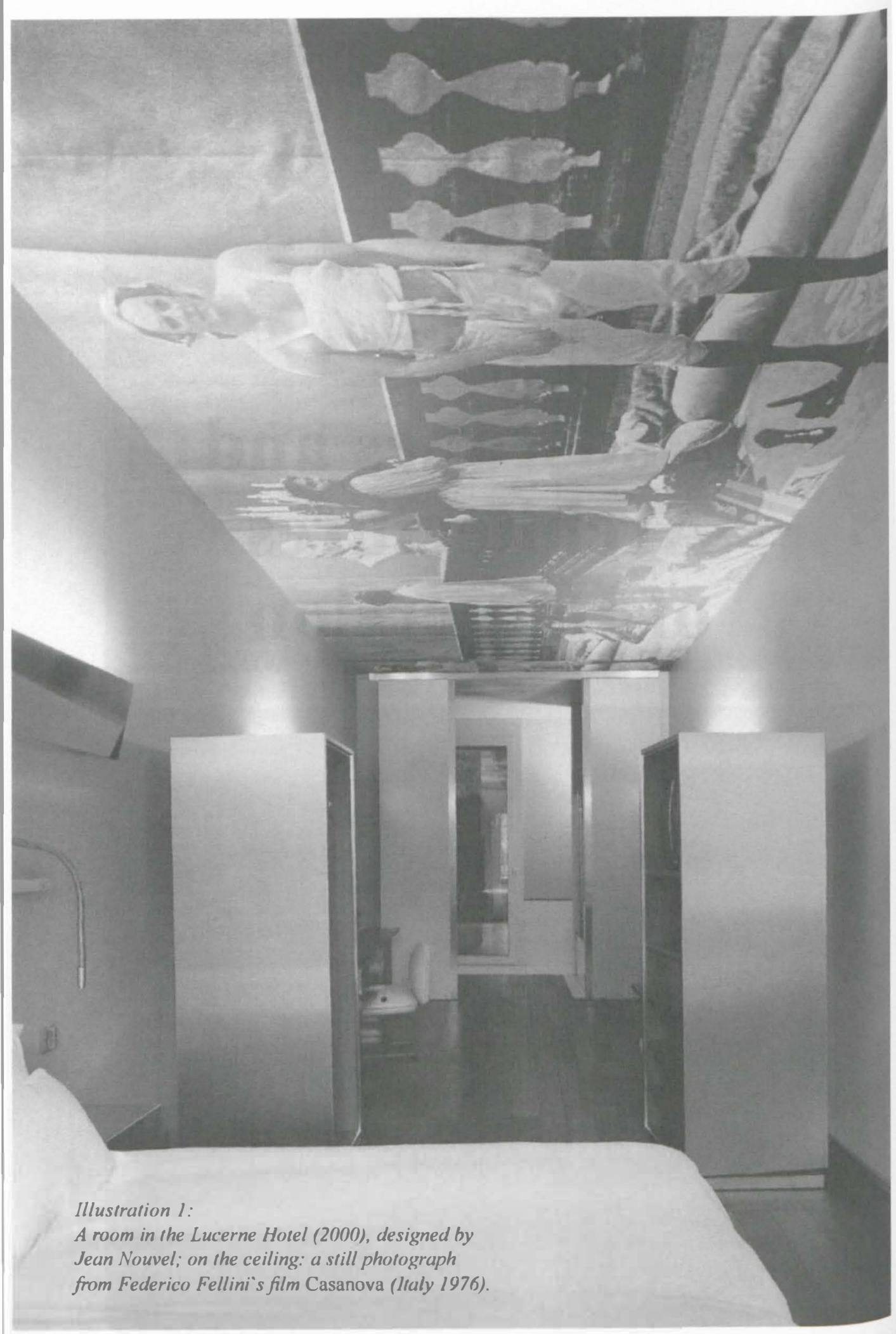




\title{
Projection Rooms \\ Film as an Immersive Medium in the Architecture of Jean Nouvel
}

\author{
Henry Keazor
}

\begin{abstract}
In her contribution to the volume Architecture and Film from 2000, the architecture historian Joan Ockman wrote: "Film has been compared to architecture almost since its inception." The numerous parallels between the visual arts, film, and architecture listed there explain why contemporary architects such as Jean Nouvel increasingly refer to and rely on the aesthetic achievements of film in the conception and realization of their building projects. By discussing several projects and buildings by Nouvel I will show how he potentiates these insights via a repertory of further immersive means that are not at the disposal of the filmic medium (these means include spatially achieved 'montages' and 'cross-fading', techniques that create fluent passages between rooms as well as architectonically crafted narrative strategies that produce suspense). Moreover, in the case of Nouvel, film itself is often made a topic of these rooms.
\end{abstract}

It may seem paradoxical at first sight to examine the question of if and how architects and their buildings make recourse to the principle of immersion, since this principle is precisely defined (according to Béla Balázs's description in his text "Zur Kunstphilosophie des Films" from 1938) as a cinematic strategy used to involve and draw in a viewer situated at some distance from the action depicted on the screen. Balázs saw this quality as being proper to film in that it destroys a principle of the traditional special arts, namely 'the distance and the segregated closeness of the artwork" ("die Distanz und die abgesonderte Geschlossenheit des Kunstwerks”; 1938/2003: 212)1:

The agile camera carries my eye and thus my consciousness along: into the heart of the picture, into the middle of the space where the action takes place. I don't see anything from the outside. I am seeing everything as the acting person must see it. I am surrounded by the figures of the film and thus entwined into its action. I am coming along, I am driving along, I am falling along - even though I physically remain seated on the same spot. ${ }^{2}$

1 Unless otherwise indicated, all translations are mine.

2 "Die bewegliche Kamera nimmt mein Auge, und damit mein Bewußtsein, mit: mitten in das Bild, mitten in den Spielraum der Handlung hinein. Ich sehe nichts von 
In the case of constructed architecture, this dissolution of the lines between the image space and the viewer's space - this drawing-in, suckingin, and diving-in - not only seems unnecessary, it does not even seem possible, since the image space and the viewer's space are one and the same. So why and how should the viewer be 'immersively' drawn into a space in which he or she already is?

If one considers this question further, however, it becomes clear that, on the one hand, immersive strategies have always been and still are relevant for architecture. On the other hand, it can be demonstrated that, in particular cases, such immersive strategies can even be apprehended as being especially necessary. This has to do with certain crises in the more recent phases of architectural history but also with building tasks, which are dictated by the specific functions some types of buildings are required to serve. The architecture of the $20^{\text {th }}$ and $21^{\text {st }}$ centuries has been reproached in various ways on the grounds that the creations developed and presented by their representatives focus primarily on concepts oriented toward an exterior effect. Consequently, they neglect the interior space in such a way that the recipients would not even feel invited to step into the building or, worse, would instead feel hindered, if not outright diverted or even repelled, from doing so (see Keazor 2010).

This - and with this we come to the above-mentioned building tasks - presents an even greater conflict with regard to the original destination and function of, in particular, public buildings (or buildings especially addressed to the public), such as theaters, concert halls, or cinemas, in which case the exterior appearance and the building should have a positive effect on the viewer.

One can thus already determine where architecture's interest in the principles of immersion and of its specific application might lie: at first sight, filmic space and the sense of immersion it creates may appear deficient in comparison with 'real' space, since filmic space only wants to make the viewers believe that here they can have experiences similar to those they would have in a real room (meaning: a personal experience of space) (cf. Agotai 2007: 15). But if we consider the means with which this is to be made possible more closely, the lesson architecture can learn from film becomes clear. Thus, in her doctoral thesis, Architekturen in

außen. Ich sehe alles so, wie die handelnden Personen es sehen müssen. Ich bin umzingelt von den Gestalten des Films und dadurch verwickelt in seine Handlung. Ich gehe mit, ich fahre mit, ich stürze mit - obwohl ich körperlich auf demselben Platz sitzen bleibe." (Balázs 1938/2003: 212 [emphasis in the original]) 
Zelluloid: Der filmische Blick auf den Raum, published in 2007, Doris Agotai writes:

The filmic space is a two-dimensionally represented pictorial space, which, in the form of a projection of light, develops an illusionistic-immersive effect. [...] In contrast, the perception of architecture is tied to the movement and direct physical presence of the viewers. While film aims at directing the viewer's emotionality, architecture is predominantly determined by functional aspects. ${ }^{3}$

It is exactly this presumption - that architecture is mostly determined by 'functional aspects' - to which more and more positions in the $20^{\text {th }}$ and $21^{\text {st }}$ centuries have objected, referring occasionally to earlier architectural traditions while at the same time demanding the 'emotionality' usually claimed by film: rooms should not just 'function', but should also convey something, address the physically present visitors as they move through these spaces, involve them. In this light, the definition of 'immersion' as furnished by Agotai can also be applied to architecture:

Immersion can be understood as a process that triggers a mental absorbance. Hereby the critical distance between work and viewer is reduced and an emotional involvement becomes the goal. The space [pictorial space] thus gains power of suggestion over the viewer $[\ldots] .^{4}$

In order to gain this kind of power of suggestion over the viewers and to convey something to them, architecture has to develop strategies for designing rooms and staging the experiences emanating from them, for structuring the visitors' physical presence and movement in order to make them complete, and rounding them off via the viewers' mental as well as emotional involvement.

3 "Der filmische Raum ist ein zweidimensional dargestellter Bildraum, der als Lichtprojektion eine illusionistisch-immersive Wirkung entfaltet. [...] Die Wahrnehmung von Architektur dagegen ist an die Bewegung und direkte körperliche Präsenz des Betrachters gebunden. Während der Film die Emotionalität des Zuschauers zu steuern versucht, wird die Architektur weitgehend von funktionalen Gesichtspunkten bestimmt." (Agotai 2007: 19) Agotai takes the opposite approach to the procedure presented here: she considers filmic means of composition, such as editing and framing, from the perspective of architecture in order to understand their effects and how they are received in the context of film.

4 "Immersion kann als Prozess verstanden werden, der eine mentale Absorbierung auslöst. Dabei wird die kritische Betrachterdistanz gemindert und eine emotionale Involvierung angestrebt. Der Raum gewinnt so an Suggestionsmacht über den Betrachter [...]." (Ibid.: 19) 
Agotai's statement that with the help of filmic means of design, directorial staging intentions are achieved (cf. ibid.: 43), could thus refer to architecture as well, which can also develop such directorial and staging intentions and recur to filmic means of design in order to achieve its aims.

The fact that such directorial intentions, which are aimed at the visitor's perception, are by no means new to architecture is shown not only by the recourses of directors such as Sergei Eisenstein to earlier architectural analyses but also by positions such as the one held by the psychologist and philosopher Theodor Lipps. Lipps began working and teaching in Munich in 1894 and (as Robin Curtis has emphasized; cf. 2008a: 12f.; 2008b: 100f.) examined architecture and its elements as objects of human empathy in his text Raumästhetik und geometrischoptische Täuschungen, published in June 1897. Beginning with the observation that architecture is 'not just space in general, but shaped space' ("nicht nur Raum überhaupt, sondern geformter Raum"; Lipps 1897: 11) - and thus also encompasses formal elements that the human consciousness does not perceive neutrally but through interpretation and association - Lipps drew the conclusion that, essentially, architecture is also 'animation of space' ("Raumbelebung"; ibid.: 12). According to Lipps, this is because humans conceive the forms used by architecture involuntarily and spontaneously (and this means: beyond all conventions determined in the sense of symbolism) against the background of their experiences and, in an emphatic way, as expressions of interactions and reactions. Lipps's examination of the effect of the appearance of a Doric column has become famous in this context. According to him, the column erects itself in the perception of the viewer and thus triggers certain associations:

The powerful concentration and raising of the Doric column is pleasant for me like my own powerful concentration and raising which I can remember and like the powerful concentration and raising which I perceive in others. I am thus in $\mathrm{s} \mathrm{y} \mathrm{m} \mathrm{p}$ a t h y with the way the Doric column behaves or operates an inner vitality, since I recognize here a way of behavior, proper to nature, and at the same time also my own way of conduct that makes me cheerful. Thus, all joy about spatial forms - and we can add: all aesthetic joy in general - is an exhilarating feeling of sympathy [emphasis in the original]. ${ }^{5}$

5 "Das kraftvolle sich Zusammenfassen und Aufrichten der dorischen Säule ist für mich erfreulich, wie das eigene kraftvolle Zusammenfassen und Aufrichten, dessen ich mich erinnere, und wie das kraftvolle Zusammenfassen und Aufrichten, das ich an einem Anderen wahrnehme, mir erfreulich ist. Ich s y m p a t h i s i r e mit dieser Weise der dorischen Säule 
According to Lipps, the viewer is affected by such phenomena that shape a room and, in this way, is placed in relation to them in an affective way. By purposefully employing insights into such principles of the operation of forms, the architect is able to increasingly incorporate the viewer into his buildings. This is specifically achieved through the power of suggestion of the buildings' rooms and by isolating viewers in the sense of removing them from their distanced views and immersing them in a more emotional involvement with the structure.

At the time Lipps wrote his text, film, which had been introduced in 1895 in Berlin and Paris, was just two years old ${ }^{6}$. Therefore, at that time, one could not foresee the extent to which aspects as interesting as they are relevant to architecture would emerge from this new medium. Soon after, however, what Anthony Vidler described in 1993 came true:

Since the late nineteenth century, film has provided a laboratory for the definition of modernism in theory and technique. As the modernist art par excellence, it has also served as a point of departure for the redefinition of the other arts, a paradigm by which the different practices of theater, photography, literature, and painting might be distinguished from each other. Of all the arts, however, it is architecture that has had the most privileged and difficult relationship to film. (1993: 45)

A brief look into their history shows that both art forms were actually, very early on and increasingly, associated with one another: "Film has been compared to architecture almost since its inception", as the architectural historian Joan Ockman opened her contribution to the volume Architecture and Film (2000: 171). In fact, in his manifesto on the seventh art from 1911, the Italian futurist and film theorist Ricciotto Canudo, who lived and worked in Paris, established a hierarchy according to which music and architecture are the closest to film among the other arts (cf. Weihsmann 1988: 45). This constellation was emphasized even more by the architect Le Corbusier in 1928 when he said:

sich zu verhalten oder eine innere Lebendigkeit zu bethätigen, weil ich darin eine naturgemässe und mich beglückende eigene Verhaltungsweise wiedererkenne. So ist alle Freude über räumliche Formen, und wir können hinzufügen, alle ästhetische Freude überhaupt, beglückendes Sympathiegefühl.” (Lipps 1897: 7)

6 See the bioscope, presented by the Skladanowsky brothers in Berlin on November 1,1895 , or the cinematograph, publicly presented by the Lumière brothers on December 28,1895 , in Paris. 
Illustration 2:

The $19^{\text {th }}$-century façade of the Lucerne Hotel from the outside, with glimpses of the different ceiling images inside.

"Architecture and the cinema are the only two arts of our time" (qtd. Cohen 1987/1992: 49)7.

Possible reasons for this correlation are, firstly, the parallels regarding the conditions and processes in the production of film and architecture, as they are often stressed by directors as well as architects and architecture theorists: "The architect is a sort of theatrical producer, the man who plans the setting for our lives [...]. He sets the stage for a long, slow moving performance [...]" (Rasmussen 1959: 10f.). Furthermore, in both disciplines, directors and architects are subjected to financial, hierarchical, and organizational constraints, since they both have to take care not to exceed their budgets; both must work in a team; both have an authority to whom they have to answer, whether in the figure of a client or a producer; and both must try to realize their ideas in coordination with these authorities. Moreover, directors such as Vsevolod Pudovkin have voiced their view that a film is not shot but constructed like a house (see Pudovkin $1928 / 2003)^{8}$. Parallels between the two art forms, however, can also be drawn in light of the fact that both deal with the dimensions of time and space, the common means given to and used by architecture and film, and the results achieved therewith.

Or, to put it in the words of the French architect Jean Nouvel (born 1945): both art forms produce images (which is also why he considers himself an "architecte-créateur d'images"; 1987: 23). Nouvel himself

7 "Le cinéma et l'architecture sont les deux seuls arts de l'époque contemporaine" (qtd. Cohen 1987: 72). This quote is from an interview Le Corbusier gave during a visit to Moscow in 1928.

8 Rasmussen gives this idea yet another twist when he specifies: "The building is produced like a motion picture without star performers, a sort of documentary film with ordinary people playing all the parts" (1959: 14). 
repeatedly stressed the fact that, in architecture, there is also a tendency toward two-dimensionality ${ }^{9}$. The way this is expressed in his work can be observed, for example, in the hotel he designed and built in Lucerne between 1998 and 2000 (cf. Nouvel 2008b: 419; 96-103 illustrations). Here, the architect has substituted the ceiling frescoes, often present in magnificent and representative early modern buildings, with huge film stills, hovering above the heads of the hotel guests inside (see $\mathrm{Il}$ lustration 1), but at the same time still visible from the outside (see Illustration 2). In this way, these ceiling images also have the function of intriguing and teasing passersby in such a way that they begin to wonder what the interior rooms look like and are thus lured into the hotel.

Such references concerning film are frequent in Nouvel's work, from the use of aperture blinds, which frame the visible landscape in the case of the windows of the Institute du Monde Arabe, constructed between 1981 and 1987 (cf. 2008a: 396f.; 74-93 illustrations), to this recourse to, once again, film stills in the case of his building at the Anděl metro station in Prague, built between 1999 and 2000 (cf. 2008b: 411; 66-71 illustrations $)^{10}$. As these examples show, these references to film are not merely quirky, isolated cases in the French architect's oeuvre, but are deeply grounded, on the one hand, in an enthusiasm for cinema - which, according to Nouvel himself, began in his early childhood ${ }^{11}$ - and, on the other hand, in his fundamental examination of the possibilities and range of the filmic medium.

9 Jean Nouvel in a talk with Paul Virilio: 'I also pretend (and this always causes violent reactions) that there is, in architecture, a tendency towards two-dimensionality.' ("Je prétends aussi [et cela suscite toujours de violentes réactions] qu'existe, en architecture, une tendance à la bidimensionnalité"; qtd. Goulet 1987: 107).

10 For this building, cf. also Keazor 2011: $393 \mathrm{f}$.

11 For the interview by Françoise Puaux with the architect, see Puaux 1995. 
Illustration 3:

Jean Nouvel's design for the auditorium of the restructured Venice Palazzo del Cinema (1990) in its two states: a) before the projection of a film, b) during the projection.

while immersing the audience in the landscape ${ }^{12}$. During screenings, the window would have been covered with a screen onto which - after the architectural/scenic immersion - the films would have been projected, thereby creating the filmic immersion (see Illustration $3 b$ ).

However, in the context of his projects, Nouvel has especially and repeatedly referred to phenomena that are central to film, such as sequence, the succession of images, on the one hand, and, on the other hand, montage, "la succession des séquences" (Puaux 1995: $105)^{13}$, which creates the illusion of a coherence of movement and action in a film in the first place. The architect has also referred to the fact that every image - and, in the case of narrative cinema, even the entire film - aims at making itself forgotten. The audience is made to believe that they are following a flow of observed events and not looking at single film scenes merely attached to each other: 'I like the film that makes me forget the camera as I like the architecture that makes me forget the constructive means.' ${ }^{14}$

With this kind of recourse to the procedures of sequencing and of montage, Nouvel positions himself at an almost classical intersection between architecture and film: in this respect, it is telling that, between 1920 and 1940, both the architect Le Corbusier and the film director Sergei Eisenstein referred to the principles stated in Histoire de l'architecture, by the architectural historian Auguste Choisy, in order to illustrate the principles they propagated. In his work, Choisy dem-

12 This concept has a precursor in an unexecuted idea by Gottfried Böhm, who planned such a building with his design for a theater in Bonn in 1959: the wall was to open behind the stage in such a way that not only could one look from the exterior into the room, but the exterior could be included in the action on stage, making it part of the set. The plan even involved the idea of opening up the wall behind the stage in such a way that inside and outside, stage and reality, would have been conflated. For more on this project, cf. Voigt 2006: 254, No. 103.

13 Cf. also the statement by Odile Fillion: "He no longer regarded architectural space as simple volume, or combinations of sets of images, but rather as a series of sequences" (1997: 119).

14 "J'aime le film qui me fait oublier la caméra, comme j'aime l'architecture qui me fait oublier les moyens constructifs" (Nouvel 1987: 24). 
onstrates that the seemingly asymmetrical and non-axial layout of the Parthenon in Athens (a mysterious thorn in the sides of French Hellenists of the $19^{\text {th }}$ century, who extolled symmetry and order as a commandment) could be explained by the fact that the whole complex of buildings constituting the Acropolis was conceived as a series of four main 'pittoresque' tableaus, composed of buildings and statues, to be experienced while approaching and perambulating the complex (cf. Choisy 1899: 413-422). According to Choisy, the Greeks would have regarded angular views as being 'plus pittoresque' than the more majestic frontal views. The visitor would have thus been guided on an oblique route through a series of tableaus, among which the seeming asymmetry of the whole complex would have been balanced and corrected by the lateral approach (see Etlin 1987). In order to show this concept, Choisy illustrates the different stops along this ideal approach in the form of a cinematic storyboard (cf. Bois/Glenny 1989: 114). It is exactly this series of views presented in words and images that Le Corbusier as well as Eisenstein adopted in their texts. In his series of articles written for the review L'esprit nouveau between 1920 and 1922, which were later published as a book in 1923 under the title Vers une architecture, Le Corbusier quotes Choisy's illustrations (see $1923 / 2007^{15}$ ) and, three years later, praises his Histoire as the most dignified work on architecture (cf. 1926: 116). Most importantly, however, this work inspired Le Corbusier to develop his own concept of a "promenade architecturale" as a central category of architecture (cf. Etlin 1987: 273). With reference to his own buildings, such as the Maison La Roche-Jeanneret (1923/1924) and the Villa Savoye (19281931), Le Corbusier demonstrated, in an exemplary way, the realization of these principles in the context of modern architecture: 'In this house, one encounters a true "promenade architecturale", offering constantly changing, unexpected, and sometimes baffling views. ' 16 ' [...] the architectural spectacle offers itself to one's eye bit by bit: one follows a route, and a great variety of prospects unfolds. ${ }^{17}$

15 See, for example, the illustration to the chapter heading "Trois rappels à messieurs les architects - III: Le Plan".

16 "Dans cette maison-ci, il s'agit d'une véritable promenade architecturale, offrant des aspects constamment variés, inattendus, parfois étonnants" (Le Corbusier 1947/1929-1934: 24).

17 “[...] le spectacle architectural s'offre de suite au regard: on suit un itinéraire et les perspectives se développent avec une grande variété" (Le Corbusier 1948/1910-1929: 
In the context of his Entretien avec les étudiants des écoles d'architecture in 1943, he finally expressed his sentiment that, by observing and following the courses prescribed by architecture, a specific frame of mind would be evoked ${ }^{18}$. The character this frame of mind can have becomes clear in a remark made by Nouvel, who, for his part, claims to convey to the viewer a specific emotion he has previously experienced himself. In this objective, he sees another parallel between the architect and the director:

To experience a sensation - to be moved - to be aware of this - to have via one's own emotion the perversion to analyze this emotion - to remember it - to initiate a whole strategy in order to imitate this emotion, to enhance it in order to better convey it to others and to assure that it is made felt - for the joy of shared pleasure. All of this is what it means to be a director of film or of architecture. ${ }^{19}$

This precisely was also the objective of Eisenstein, who wanted to develop the cinematographic means to achieve this so that (as YveAlain Bois and Michael Glenny sum up) "the spectator will obtain an impression of the object or - moreover - the impression which the author wishes to induce in transforming the relationships of reality, that which he wants to inscribe for the perception" (1989: 111). The most efficient procedure in this respect was discovered by Eisenstein in the combined possibilities of the sequence and its 'juxtaposition' in the montage (cf. ibid.; Eisenstein 1938/1991: 66). For Eisenstein, Choisy's analysis of the Acropolis thus functions as evidence to the fact that these two procedures could have already been inscribed into architecture long before the invention of film: " $[\ldots]$ it is hard to imagine a montage sequence for an architectural ensemble more subtly composed, shot by shot, than the one our legs create by walking among the buildings of the Acropolis", Eisenstein states, before adding a long quote from Choisy's Histoire in word and image (1938/1991: 61-66), in his article "Montage and Architecture", written between 1937 and 1940 .

60).

18 Cf. Le Corbusier 1943/1957, without pagination, chapter on architecture, no. 5.

19 "Éprouver une sensation - être ému - en être conscient - avoir la perversion à travers son émotion d'analyser cette émotion - s'en souvenir - mettre en œuvre toute une stratégie pour la simuler, l'amplifier, pour mieux la donner aux autres et, à coup sûr, la faire éprouver - pour le bonheur du plaisir partagé. C'est tout cela être réalisateur du cinéma ou d'architecture." (Nouvel 1987: 23) 
In his 1971 study Sur l'espace architectural, Philippe Boudon emphasized that, ideally, built architecture is a kind of a projection of results developed in the imagination of the architect onto a defined space. Furthermore, according to Boudon, the perception of exactly this architecture, in particular, means to perceive and experience these thoughts and ideas, which have been developed in the mind of the architect: "The mental process that goes on in the mind of a person who observes a building in this way is very much like that which goes on in the mind of an architect when planning a building" (qtd. Rasmussen 1959: 44) ${ }^{20}$.

In order to project his ideas concerning the desired perception of a room and the visitor's involvement onto the space as efficiently and clearly as possible, Nouvel enhances the potential already given to architecture through sequence and montage by potentiating these with other filmic means: not only should the viewer walk through his buildings and explore them in the context of a "promenade architecturale", but Nouvel also aims at extending the possibilities generally given to the architect when inscribing alternating and superimposing sequences onto the structure of a building and making the viewer experience certain aspects and views in order to convey related emotional sensations. Nouvel expanded this with the help of a very spe-

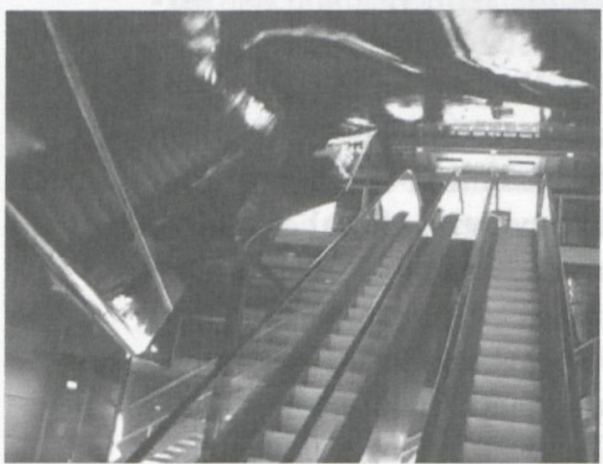

Illustration 4:

Elevators in Jean Nouvel's Lyon Opera House (1993) carry the visitors toward the upper levels from where the huge volume of the black auditorium is looming.

20 Here, I am following the later German translation of Boudon's book, which was published under the title Der architektonische Raum: Über das Verhältnis von Bauen und Erkennen: 'Architecture is the projection of the architect's imagination of the concrete space.' ("Architektur ist die Projektion der Vorstellung des Architekten vom konkreten Raum"; 1991: 58). 'Perceiving architectonic space in a building means to perceive, at the same time, something that has been thought before.' ("Architektonischen Raum in einem Bauwerk wahrnehmen, heißt zugleich auch etwas zuvor Erdachtes darin wahrnehmen"; ibid.: 76). 


\section{Illustration 5:}

After having to walk on loud metal grid floors, an acoustic lock, illuminated in bright red, awaits the visitors; through the lock they can enter the auditorium of the Lyon Opera House.

cific and targeted direction of light, sound, and color, which are also known in cinematic contexts.

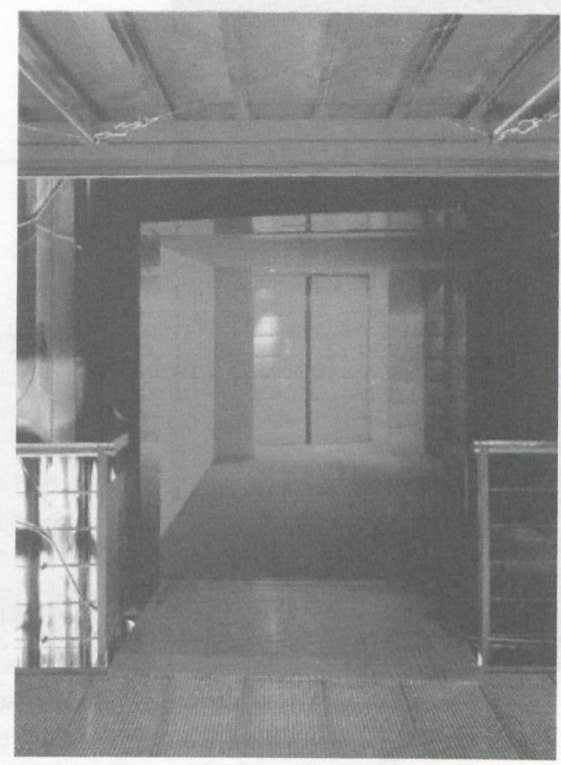

Two examples illustrate this: in 1986, after winning the competition, Nouvel received permission to completely gut the building of the Lyon Opera, built in 1831 by AntoineMarie Chenavard and Jean-Marie Pollet, and to extend its premises considerably through the addition of underground levels as well as a large glass dome roof (cf. Nouvel 2008a: 402-404; 158-179 illustrations).

The modernization of housing technology and the more efficient use of the building aside, this renovation, along with an extension completed in 1993, also gave the architect the chance to take the contrasts between the old, stony exterior and the new, modern interior as a starting point for a designed course. Together with the subtle color compositions, especially the lighting conditions, differences in dimensions (which address optical perception), surfaces (which address haptic perception), and greatly varying acoustic experiences interlace with the visitors' corporeal experiences as they move through the building, creating a dramatically structured sequence. Thus, when approaching the opera in the evening, visitors already encounter the chromatic triad of black, yellow, and red, which guides them toward the interior. Here inside the lounge, permeated by golden reflections, they then encounter the black, glistening skin of the voluminous auditorium looming above, placing the exterior walls of their destination before their eyes (see Illustration 4). Escalators guide them silently upward toward this destination, where, however, they then have to continue on their way by foot via a system of walkways, which, because of their metal grid floor, resonate loudly with the visitors' footsteps. A respective contrast then awaits the visitors at the entrance to the auditorium, where they must first pass through a soundproof lock, illuminated in red and lined with sound-deadening material (see Illustration 5), before the black auditorium, illuminated 


\section{Illustration 6:}

The long sequence of the passage, punctuated by lights and windows, which leads toward the auditorium of the KKL Lucerne (1998).

by small lights, finally opens up in front of them: 'a true "promenade architecturale", offering constantly changing, unexpected, and sometimes baf-

fling views'.

This consequent use of a sequence consisting of different and sometimes contrasting impressions concerning color, sound, and physical experience works as a kind of strategy of abduction, which aims at carrying the visitors away from everyday life toward the anticipated pleasure of the art form of opera, while simultaneously time-sensitizing and preparing them for the acoustic as well as optical sensations which are paramount there. At the same time, such a dramaturgy of abduction and rapture refutes the main objection that is often voiced toward such a parallelization between architecture and film, according to which architecture does not have narration at its disposal. Even a fervent critic such as Kester Rattenbury, who normally argues against this parallel, had to admit the following in an article on the architecture of Jean Nouvel: "The architectural direction is undeniably potent: linking a filmic perception with personal experience of architecture" $(1994: 35)^{21}$.

Nouvel has designed similarly structured passages in which, each time, particular stations are assembled to form a homogenous 'course', in subsequent public buildings, such as in the Culture and Convention Center in Lucerne, the so-called KKL, a complex finished in 1998, which includes a concert hall, conference rooms, and exhibition spaces (cf. Nouvel 2008b: 404f.; 6-27 illustrations) ${ }^{22}$. In the 1998 documentary film Jean Nouvel - Aesthetics of Wonder by Beat Kuert, Brigitte Métra, the architect who cooperated with Nouvel on the KKL project, explains:

21 For the discussion of the "debated, if not contested" term 'narrative', cf. Koeck, who states that "film forms a dynamic space that is held together by a narrative" (2013: 21). This is something that can also be applied to architecture if one interprets the notion 'narrative' as a "series of events or actions" (ibid.: 19) that is perceived as somewhat structured and meaningful.

22 For this building, cf. Keazor 2011: 405f. 
Jean often uses film metaphors. That's because he creates sequences for his buildings. He wants the visitor to go through his buildings as though they were in a film, with different shooting sequences and emotions, accompanying every change of setting. His aim is to create emotions. You enter the buildings through sheets of glass, [...] so you pass from the exterior to the interior as if by magic, with no door as such. We tried to avoid anything that might serve as a reminder of the fact that this is a door. The function is forgotten. You are left with the emotion. The public [...] proceeds to the lower floor. Space is somewhat restricted in the basement as the ceilings are low. In fact, it's only as you approach the hall [the concert hall] that the space opens up. You now have a full vertical view - a round-angle perspective of the wooden shell of the concert hall. It resembles a musical instrument that stretches upward beyond the terrace. The way leading to the hall may almost be considered an initiation. In cooperation with Alain Bony, the artist who worked on the colors and painting, Jean also focused on the materials. As a result, we have shiny, polished surfaces alternating with matte surfaces. The length of this passage is emphasized by the punctuations of light - we've worked on every detail so that these small openings wouldn't look like windows. The idea was to conceal the window frames that are practically absorbed by the plasterwork so that all that is left is a glass-covered hole. Full focus is on the view. [...] This punctuated lighting leads us to the hall [see Illustration 6]. After the long sequence of light, you enter into a grey, pleated lock another sequence, an intermediary buffer, and presto, you find yourself in a grey elephant-skin box. You can touch the wide, grey pleats ${ }^{23}$. You get the impression you are in a padded cocoon. It's an acoustic lock. Sound and light are dulled by the anthracite grey color of the carpet and the floor. So you pass through this area - this intermediate sequence between the large foyer and the long corridor and you find yourself in this small room. What next? The white hall! It's like in a script - we work as they do in the movies. ${ }^{24}$

23 In this respect, Nouvel's architecture also fulfills the claims voiced by the supporters of the so-called Phenomenology of Architecture movement, such as Steven Holl, Juhani Pallasmaa, and Alberto Pérez-Gómez, who, in their writings, have repeatedly asked for an architecture that challenges "ocularcentristic" or "retinal" conceptions (as Pallasmaa calls buildings exclusively addressed to the sense of vision) in favor of designs that also respond to the senses of hearing, smell, and taste, but most of all, touch. As Pallasmaa puts it: "All the senses, including vision, can be regarded as extensions of the sense of touch" (2005: 42). See also Holl/Pallasmaa/Pérez-Gómez $1994 / 2008$.

24 The transcript follows the English translation of Métra's statements in the film Jean Nouvel - Aesthetics of Wonder (dir. Beat Kuert, Switzerland 1998). 


\section{References}

Agotai, Doris (2007). Architekturen in Zelluloid: Der filmische Blick auf den Raum. Bielefeld: transcript.

Albersmeier, Franz-Josef, ed. (2003). Texte zur Theorie des Films. $5^{\text {th }}$ ed. Stuttgart: Reclam.

Balázs, Béla (1938/2003). "Zur Kunstphilosophie des Films". Albersmeier, ed. 201-223.

Bois, Yve-Alain, Michael Glenny (1989). "Sergei M. Eisenstein: Montage and Architecture". Assemblage 10: 110-131.

Boudon, Philippe (1971). Sur l'espace architectural: Essai d'épistemologie de l'architecture. Paris: Dunod Editeur Bordas.

- (1991). Der architektonische Raum: Über das Verhältnis von Bauen und Erkennen. Basel/Berlin/Boston, MA: Birkhäuser.

Choisy, Auguste (1899). Histoire de l'architecture. Vol. 1. Paris: Gauthier-Villars.

Cohen, Jean-Louis (1987). Le Corbusier et la mystique de l'USSR: Théories et projets pour Moscou: 1928-1936. Brussels: Mardaga.

- (1987/1992). Le Corbusier and the Mystique of the USSR: Theories and Projects for Moscow: 1928-1936. Transl. Kenneth Hylton. Princeton, NJ: Princeton UP.

Curtis, Robin (2008a). "Einführung in die Einfühlung". Robin Curtis, Gertrud Koch, eds. Einfühlung: $\mathrm{Zu}$ Geschichte und Gegenwart eines ästhetischen Konzepts. Munich: Fink. 11-30.

- (2008b). "Immersion und Einfühlung: Zwischen Repräsentationalität und Materialität bewegter Bilder". montage AV 17/2: 89-107.

Eisenstein, Sergei M. (1938/1991). "Montage and Architecture". Selected Works. Vol. 2: Towards a Theory of Montage. Eds. Michael Glenny, Richard Taylor. London: British Film Institute. 59-81.

Etlin, Richard A. (1987). "Le Corbusier, Choisy, and French Hellenism: The Search for a New Architecture". The Art Bulletin 69/2: 264-278.

Fillion, Odile (1997). "Life Into Art, Art Into Life: Fusions in Film, Video and Architecture". François Penz, Maureen Thomas, eds. Cinema and Architecture: Méliès, Mallet-Stevens, Multimedia. London: British Film Institute. 118-121.

Goulet, Patrice (1987). Jean Nouvel. Milan: Electa.

Holl, Steven, Juhani Pallasmaa, Alberto Pérez-Gómez (1994/2008). 
Questions of Perception: Phenomenology of Architecture. San Francisco, CA: William Stout Publishers.

Keazor, Henry (2010). “'Avis de recherche': Verlorene Zeit und gefundener Raum in Jean Nouvels INIST". Burcu Dogramaci, Simone Förster, eds. Architektur im Buch. Dresden: Thelem. 211-226.

- (2011). "'L'architecte fait son spectacle': Medienrekurse in der Architektur Jean Nouvels". Andreas Beyer, Matteo Burioni, Johannes Grave, eds. Das Auge der Architektur. Munich: Fink. 377420.

Koeck, Richard (2013). Cine I Scape: Cinematic Spaces in Architecture. New York, NY/London: Routledge.

Le Corbusier (1923). Vers une architecture. Paris: Editions Crès.

- (1923/2007). Toward an Architecture. Introd. Jean-Louis Cohen. Transl. John Goodman. Los Angeles, CA: Getty Research Institute.

- (1926). Almanach d'architecture moderne. Paris: Editions Crès.

- (1943/1957). Entretien avec les étudiants des écoles d'architecture. Paris: Editions de Minuit.

- (1947). "Villa Savoy à Poissy". Euvre complète. Vol. 2: 1929-1934. Ed. Pierre Jeanneret. $4^{\text {th }}$ ed. Zurich: Editions d'architecture. 23-31.

- (1948). "2 Hôtels particuliers à Auteuil (La Roche-Jeanneret)". CEuvre complète. Vol. 1: 1910-1929. Ed. Pierre Jeanneret. $5^{\text {th }}$ ed. Zurich: Editions d'architecture. 60-67.

Lipps, Theodor (1897). Raumästhetik und geometrisch-optische Täuschungen. Leipzig: Barth.

Nouvel, Jean (1987). "Cinéma, architecture: Une envie de deserter". L'architecture d'aujourd' hui 254: 23-28.

- (2008a). Jean Nouvel by Jean Nouvel. Vol. 1: 1970-1992. Ed. Philip Jodidio. Hong Kong et al.: TASCHEN.

- (2008b): Jean Nouvel by Jean Nouvel. Vol. 2: 1992-2008. Ed. Philip Jodidio. Hong Kong et al.: TASCHEN.

Ockman, Joan (2000). "Architecture in a Mode of Distraction: Eight Takes on Jacques Tati's Playtime". Mark Lamster, ed. Architecture and Film. New York, NY: Princeton Architectural Press. 171-195.

Pallasmaa, Juhani (2005). The Eyes of the Skin: Architecture and the Senses. Chichester: Wiley.

Puaux, Françoise (1995). "Entretien". CinémAction 75: 104-106.

Pudovkin, Vsevolod (1928/2003). "Filmregie und Filmmanuskript: Einführung zur ersten deutschen Ausgabe". Albersmeier, ed. 70-73. Rasmussen, Steen Eiler (1959). Experiencing Architecture. Cambridge, MA/London: MIT Press. 
Rattenbury, Kester (1994). "Echo and Narcissus". Architectural Design Profile 112: 35-37.

Vidler, Anthony (1993). "The Explosion of Space: Architecture and the Filmic Imaginary". Assemblage 21: 44-59.

Voigt, Wolfgang, ed. (2006). Gottfried Böhm. Exh. cat. Frankfurt am Main: Deutsches Architekturmuseum, 26 August - 5 November 2006. Berlin: Jovis.

Weihsmann, Helmut (1988). Gebaute Illusionen: Architektur im Film. Vienna: Promedia.

\section{Picture Credits}

Ills. 1, 2: Fernando Márquez Cecilia, Richard Levene, eds. (2002). El Croquis 112/113: Jean Nouvel - 1994/2002. Madrid: El Croquis Editorial. 150, 139; Ills. 3a, 3b: Jean Nouvel (1999). Una lezione in Italia. Milan: Skira. 57; Ill. 4: archive of the author; Ill. 5: Olivier Boissière (2001). Jean Nouvel. Paris: Editions Pierre Terrail. 78; Ill. 6: Philip Jodidio (2012). Jean Nouvel 1945: Donneur de formes. Hong Kong et al.: TASCHEN. 52. 